\title{
INEQUALITY OF LIVING STANDARDS IN RUSSIA: INTERNAL AND INTERNATIONAL CONTEXT (THE EARLY 1990S AND THE 2000S)
}

The article studies the relationship of social groups about income distribution and goods consumption.

It is dedicated to the internal and international aspects of inequality of living standards in Russia during the period of capitalist transformations of 1990-2000's. Problems of the dynamics of inequality in living standards are analyzed. Methods of comparative analysis and comparison of performance indicators with normative social standards are used. On this basis, the population is classified into social groups and then follows the analysis of their social position. Such indicators are used: income inequality by consumption; inequality by housing, by education and health care availability. Russia is compared with countries of G20. Social inequality reasons in Russia are revealed.

The obtained results can be applied within national economic and social policy.

The findings indicated that the high social inequality in Russia undermines the ability of a large part of the population to be «included» in economic growth, for it limits access to its results. In such situation, an attempt to solve both the problem of speeding up economic growth and the eradication of poverty cannot lead to success if appropriate measures to reduce social inequality are not developed and implemented.

Keywords: Social inequality, living standard, normative consumer budgets, G20, Gini index, Russia

\section{Methodology of research}

Inequality will be considered as a differentiation of the population by living conditions, the level and structure of consumption, opportunities to realize individual abilities. Inequality leads to a deprivation of individual rights to dignity and respect.

\footnotetext{
${ }^{1}$ The time frame is specified as the end of the Soviet period and the 20th anniversary of the capitalist transformation in Russia.
}

To describe various indicators of inequality the following indicators of income differentiation are used mostly often: a) ratio of the average income of top 20 and bottom 20 per cent of the population (in times), b) the coefficient of average income differentiation of top 10 and bottom 10 percent of the population (times) (funds coefficient), and c) the Gini index (index of income concentration). Although, the differentiation of income is just one of the forms of inequality.

In addition, the economic inequality can be characterized by wealth accumulated by house- 
holds, and includes the following assets: 1) financial (cash savings, shares, contributions to pension funds, etc.), 2) non-financial (real estate, etc.) ${ }^{1}$.

Income is only a resource for access to goods and services like housing, education and health. Therefore, inequality manifests itself in consumption inequality, i.e. inequality in living standards. According to this criterion the following basic forms of social inequality are distinguished: 1 ) by current consumption of material goods and services, 2) by housing provision, 3 ) by access to education, and 4) by access to health care [2].

When characterizing social inequality by current consumption some authors compare the consumption of definite groups of food, consumer goods and paid services. The results of such comparative analyses usually demonstrate small size of inequality. In spite of the obvious usefulness of such approach, it seems more reasonable to assess the differentiation in consumption, not by separate products but by complex standards of current consumption. The latter is represented by normative consumer budgets of different income levels. Market consumer baskets of normative consumer budgets include all basic consumer goods and services. They are different by the structure and size of such combinations of goods and services and show matching of the actual level of life with the complex standards of consumption. So we are able to identify social groups and to reveal differentiation of living standards.

We have applied here as social standards the following consumer budgets: 1) the official subsistence minimum (SM), 2) socially acceptable consumer budget, 3) the budget of middle income, and 4) the budget of high income ${ }^{2}$ [3]. They correspond with each other by size approximately as 1 : 3: 7: 11 .

A comparison of the actual consumption of the population with these social standards lets us distinguish the following social groups which differ by standards of life: those most in need (less than $1 \mathrm{SM})$; with low income (1-3 SM); with income be-

\footnotetext{
${ }^{1}$ This aspect of economic inequality is not considered in the article. But according to special studies, Russia is a world leader in inequality measured by the share of the population in the accumulated wealth (assets). According to this indicator, 1 per cent of the population owns 71 per cent of assets, $5-82.5$ and 10 per cent of the population concentrate 87.6 per cent of all Russian assets. In contrast, one per cent of the population owns: in China and India (BRICS) -49 and 32 per cent respectively, in Africa - 44, in the U.S. - 37, in Europe - 32, in Japan - 17 per cent of country's assets. On average, one percent of world population owns 46 per cent of assets [1]

${ }^{2}$ Last three standards of consumer budget have been developed and verified at All-Russian Centre of Living Standard, Moscow.
}

low the average (3-7 SM); with average income (7-11 SM), with high income (over $11 \mathrm{SM}$ ).

Another group that characterizes the living standard includes standards of housing provision also designed by experts of All-Russian Centre of Living Standard: the lowest -7 square meters, socially acceptable $-18 \mathrm{sq} \mathrm{m}$, average $-30 \mathrm{sq} \mathrm{m}$, and high -60 or more sq $\mathrm{m}$ per person. In addition to housing provision, housing quality standards include housing characteristics, which become better as we move from lower to higher housing provision [4].

Additional features of inequality are due to different availability (consumption) of education and health care services and are determined by the level of correspondent payments.

International statistics do not allow us to identify and characterize all comparable national statistics indicators of economic and social inequality presented above. The general and specific in the development of Russian capitalism can be evaluated mainly through cross-country comparisons of economic inequality by income.

The results of the comparative analysis of population distribution by living standards

Population distribution by income used for consumption. Income used for consumption describes living standards more accurately than the real monetary income. A comparative characteristic of current consumption in different social groups is represented in Table 1 . It reflects changes over the years of capitalist transformation.

In 1990, because of the substantial additions to real consumer spending from public consumption funds there were hardly any representatives of the group in the most need in Russia. Although, the living standard of the majority was not high. About 30 percent of Russians were concentrated in the low-income households. Also, approximately $2 / 3$ of the population had an income below than average. Groups with average and high income were near 7 percent of the population.

After twenty years, the structure of society based on consumption level has changed dramatically. The segment of people in the most need grew about fifty times and reached 11.2 per cent. The share of households with low income increased by 1.8 times and amounted to 58 per cent. Currently, the two lowest groups by level of income account for almost three quarters of the population. The middle-income group was reduced by 3.4 times and now equals 3 percent of the population. The share of the high-income group remains low and is about one per cent. 
Table 1

Grouping of the population in Russia by income used for consumption, compared with consumer budgets of different levels of income (average per month, $\%$ of total population)

\begin{tabular}{|l|c|c|c|}
\hline \multicolumn{1}{|c|}{ Population groups by income } & Share of total population, \% & \multirow{2}{*}{$\begin{array}{c}\text { Changes for the period } \\
\text { (in percentage point) }\end{array}$} \\
\cline { 2 - 3 } & $\mathbf{1 9 9 0}$ & $\mathbf{2 0 1 1}$ & \multirow{2}{*}{11.0} \\
\hline $\begin{array}{l}\text { Those most in need (less than consumer basket of subsist- } \\
\left.\text { ence minimum }{ }^{*}, \mathrm{CB}\right)\end{array}$ & 0.2 & 11.2 & 26.3 \\
\hline Low income group (from 1 CB to 3 CB) & 31.7 & 58.0 & -33.4 \\
\hline Group with income below than average (from 3 CB to 7 CB) & 60.8 & 27.4 & -3.9 \\
\hline Group with average income (from 7 CB to 11 CB) & 6.7 & 2.8 & -0.1 \\
\hline Group with high income (more than 11 CB) & 0.7 & 0.6 & \\
\hline
\end{tabular}

Estimations are made by the experts of All-Russian Centre of Living Standard and are based on: [5, p. 31; 6, p. 9, 80; 7, p. 126; 8, p. 27,$134 ; 9$, p.21].

* To be correct consumer baskets of consumer budgets are compared.

The differentiation of the population by income used for consumption has grown (by a rate of funds) from 4.6 to 13.2 (by 2.9 times), and by the Gini index - from 0.227 to 0.398 (by 1.8 times). Again, the situation of the socio-economic inequality in terms of current consumption of different groups of the population can be estimated by a coefficient of the ratio of average income spent on consumption, in groups with consumption above $11 \mathrm{CB}$ and below $1 \mathrm{CB}$ (called the Bvn coefficient, in times). The Bvn co-

Groups of the population by size and quality of housing provision (on average per year, $\%$ of total amount of the population)

\begin{tabular}{|l|c|c|}
\hline \multirow{2}{*}{ Groups of the population } & \multicolumn{2}{|c|}{ Year } \\
\cline { 2 - 3 } & $\mathbf{1 9 9 4}$ & $\mathbf{2 0 1 1}$ \\
\hline $\begin{array}{l}\text { Those most in need - housing poverty } \\
\text { (below the first standard) }\end{array}$ & 7.3 & 2.3 \\
\hline $\begin{array}{l}\text { Group with low provision (above the } \\
\text { first but below the second standard) }\end{array}$ & 50.8 & 35.5 \\
\hline $\begin{array}{l}\text { Group with provision below the average } \\
\text { level (above the second but below the } \\
\text { third standard) }\end{array}$ & 32.9 & 33.8 \\
\hline $\begin{array}{l}\text { Group with the average level provision } \\
\text { (above the third but below the fourth } \\
\text { standard) }\end{array}$ & 8.4 & 18.0 \\
\hline $\begin{array}{l}\text { Group with high provision (above the } \\
\text { fourth standard) }\end{array}$ & 0.6 & 10.5 \\
\hline
\end{tabular}

Estimations are made by the expert of All-Russian Centre of Living Standard and are based on: [13].

efficient was 14.4 in 1990 and 20.8 in $2011^{1}$. In relation to 1990 the size of the coefficient rather symbolically characterized the socio-economic inequality. At that time, there was not a separate group for people in the most need. In a capitalist economy of Russia where there is a big seg-

\footnotetext{
${ }^{1}$ Estimations are made by the experts of All-Russian Centre of Living Standard based on $[5,6,7]$.
}

ment of people in the most need, there is also a huge gap between the consumption of this group and of the high income group (even with its small share in the society). The Bvn coefficient can be the most accurate method to characterize the socio-economic inequality between these groups of the society.

The first stage in the formation of Russian capitalism (from 1992 till 2000) led to a sharp economic downturn, the enrichment of a narrow layer of large private property owners, the impoverishment of the majority of the population and thus to a sharp social stratification.

In the second stage of capitalist transformation (from 2000 - till now) as a result of economic growth during the period of 2000-2008 and 20112012, the standard of living has increased in all segments of the population, but inequality has continued to rise. Thus, the rapid growth of social inequality is one of the most distinctive of Russian capitalism in from yearly 1990s till late 2000s².

Grouping of the population by housing provision. Housing inequality during the years of capitalist reforms has multiplied, as evidenced by the data in Table 2.

At the beginning of the capitalist transformation near 80 percent of the population in Russia had modest living conditions: in size from 7 to 30 sq $\mathrm{m}$ per person. Over the reviewed period, this segment of the population has "shrunk" by about 20 p.p. A reduction of housing poverty in terms of housing provision by 3.2 times accompanied by an increase of the group with high housing provision by 17.5 times.

The investments in housing have become one of the ways of capital accumulation for the wealthy Russians. While for the poor Russians, it

\footnotetext{
2 President Vladimir Putin considered this issue as «unacceptable, causing too high income inequality... excessive gap is perceived as an injustice and a source of social tension» [12].
} 
was only a statistical improvement caused by a reduction of the total population (from 148.3 to 143.0 million) during this period. Due to this factor, there was a statistical paradox - in a number of regions and cities that lost their production capacities, housing provision has increased significantly with almost no construction of new dwellings.

During the years of reforms social guarantees of getting habitation from the state for free (typical of the Soviet Union) have been completely destroyed $^{1}$. It costs almost nothing for the State to let free privatization of habitation, but now costs of its maintenance and repair have been passed on the impoverished majority. As a result, dwelling and utility bills have soared. Transparent market rent relations in the housing sector have neither been established mortgage crediting remains unaffordable for those who are most in need of housing, and buying a home is not often provided by adequate income.

Inequality in access to education and health care is the result of underfunding and superiority of market principles. In 1990, education of all levels was, but in 2010 near 40 per cent of young people getting an education (from general secondary to higher) in full or partially paid for their education. The brightest example is higher professional education. Here, in institutions of higher education, the corresponding figure was 62 per cent [14, p. 307, 310]. Polls of those who wish to get the higher professional education indicate that up to 80 per cent of parents were ready to pay in full or partially for education of their children [15, p. 84].

From 1991 to 2008 morbidity of children under the age of 14 increased by 1.5 and adolescents (1517 years) - in two times. The growth of this indicator is only partly linked to improved diagnosis, but most of it, according to experts, is caused by the deterioration of the true health. The actual incidence among children and adolescents is 1.5-2 times higher than the official statistics. [16]. Unequal opportunity to get health care is one of the main reasons for the reduced fertility, increased incidence and population decline. For 18 years (from 1992 till 2010) difference between the number of births and deaths in Russia was more than 13.1 million people. In case, current trends in population reproduction continue it can lead to a reduction of the population by the beginning of 2030 to $130-135$ million people [17, p. 106-113].

\footnotetext{
${ }^{1}$ Formally, the right to social rented habitation was proclaimed, but in fact its construction has not been launched.
}

\section{Inequality in Russia in the international context}

The rapid growth of economic inequality in Russia in the 1990-2000s is useful to compare with the trends in other economies at this time. This should help to better identify the general and the particular of Russian capitalism. The comparisons will be made with countries of the Group of Twenty (G20)2. Where possible and appropriate, additional emphasis will be placed on the BRICS ${ }^{3}$, countries, which, from one hand, are a part of the G20 and, from the other, represent the fastest-growing world economies.

International comparisons of socio-economic inequality are usually based on money income using the Gini index and an indicator of relative poverty. Since the relative poverty indicator is not measured in Russia, the international comparisons will be based on the Gini index ${ }^{4}$ (Table 3).

Economic inequality by income during the period from early 1990s to late 2000s increased in 14 of 18 countries (excluding the EU and Saudi Arabia from the list), members of the G20, including the BRICS countries (except of Brazil).

In Russia, the growth of economic inequality was explosive during 1990-1993 and then matched the average rate for G20. At the end of the 2000s, the level of inequality in Russia coincided with a median value of the Gini index for the BRICS group, i.e. in two countries (India and China) the inequality was lower, and in another two (South Africa and Brazil) - higher than in Russia.

Overall, the analysis of the dynamics of the Gini index showed that since the early 1990s to the late 2000s in Russia there was the highest growth of inequality compared to the G20 and BRICS countries $^{5}$. This period is characterized by the transition from a planned economy with low inequal-

\footnotetext{
${ }^{2}$ Members of the G20: Argentina, Australia, Brazil, Canada, China, France, Germany, India, Indonesia, Italy, Japan, the Republic of Korea, Mexico, Russia, Saudi Arabia, South Africa, Turkey, the United Kingdom, the United States of America and the European Union.

${ }^{3}$ BRICS members: Brazil, Russia, India, China, South Africa.

${ }^{4}$ The Gini index (or coefficient) reflects the dispersion of income in the range from zero (full equality of distribution) to one (maximum inequality). There are differences in statistical approaches of measurement inequality in different countries (in particular, in one case, the indicators can be calculated on the basis of data on household income, in other - on their spending). So indicators are not always fully comparable. As a rule, inequality by income is higher than inequality by spending.

${ }^{5}$ The authors did not give special consideration to the level and dynamics of economic inequality in China. Although, in special studies on China, as well as on Russia, it is recommended to distinguish two periods of economy development: within the world socialist system and after its destruction.
} 
Table 3.

Inequality level in G20 member states in yearly 1990s and late 2000s (the Gini index by household income)

\begin{tabular}{|l|c|c|c|c|}
\hline $\begin{array}{c}\text { G20 } \\
\text { country-members }\end{array}$ & Yearly 1990s & Late 2000s & Period & Changes (growth rate) for a period, \% \\
\hline Germany & 0.26 & 0.29 & $1990-2009$ & 12.5 \\
\hline France & 0.28 & 0.29 & $1996-2009$ & 4.6 \\
\hline Italy & 0.28 & 0.31 & $1991-2009$ & 13.5 \\
\hline Korea & 0.31 & 0.31 & $2006-2009$ & 11.5 \\
\hline Canada & 0.29 & 0.32 & $1990-2009$ & 8.7 \\
\hline Australia & 0.31 & 0.34 & $1995-2008$ & 4.0 \\
\hline Japan & 0.32 & 0.34 & $1995-2009$ & -2.8 \\
\hline UK & 0.36 & 0.35 & $1990-2009$ & 26.8 \\
\hline Indonesia & 0.29 & 0.37 & $1990-2008$ & 16.0 \\
\hline India & 0.32 & 0.38 & $1993-2008$ & 8.3 \\
\hline USA & 0.35 & 0.38 & $1990-2008$ & -16.1 \\
\hline China & 0.33 & 0.41 & $1993-2008$ & 6.0 \\
\hline Turkey & 0.49 & 0.41 & $1994-2009$ & $(53.8)$ \\
\hline Russia & 0.40 & 0.42 & $1994-2009$ & 0.9 \\
\hline Argentina & $(0.26)$ & $(0.40)$ & $(1990-1993)$ & -8.5 \\
\hline Mexico & 0.45 & 0.46 & $1992-2009$ & -9.4 \\
\hline Brazil & 0.52 & 0.48 & $1994-2008$ & 3.1 \\
\hline South Africa & 0.61 & 0.55 & $1993-2008$ & - \\
\hline Saudi Arabia & 0.67 & 0.70 & $1993-2008$ & - \\
\hline
\end{tabular}

Composed and estimated by the authors based on: $[18 ; 19 ; 20 ; 6$, c. 80$]$.

* Countries are ranked by increasing level of inequality by the end of the 2000 s.

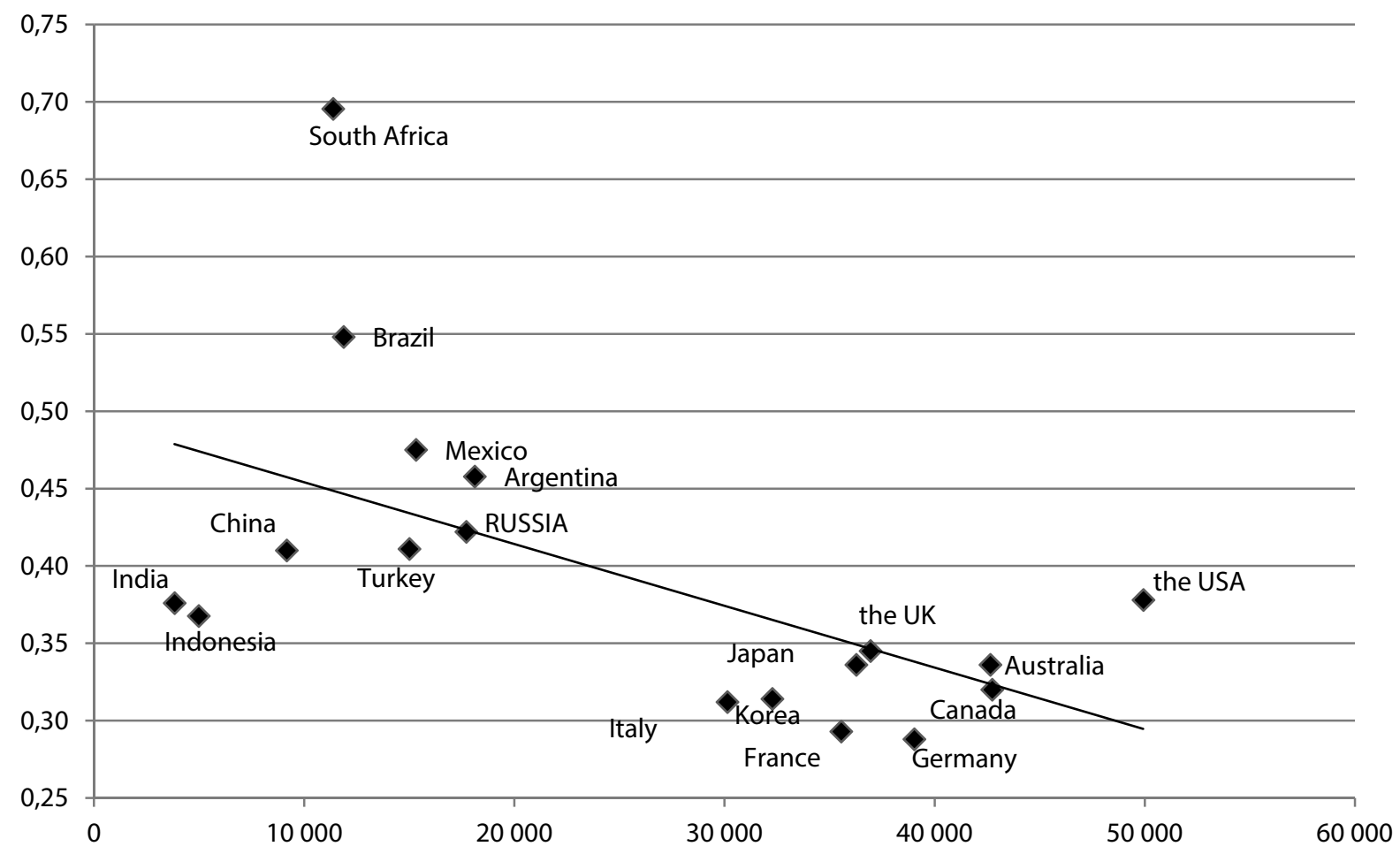

Fig. G20 countries comparison by GDP per capita and the Gini index in the late 2000s Composed by the authors based on: [18, 20,21] 
ity to a capitalist economy with high inequality based on non-economic allocation of resources in the 1990s, oligarchic model of capitalism, and a weak power of state in the 2000s. Against the overall growth of economic inequality in the G20 and BRICS its growth in Russia is quantitatively and qualitatively different.

For a comparative analysis of the size, of inequality it is not enough to apply the Gini index only. According to a common agreed approach the height of inequality in a country should be assessed by comparison of the national Gini index and the size of per capita gross domestic product (GDP) in purchasing power parity (PPP) (Table 4). Thus, the effect of economy size and structures, as well as resources to provide living standards, on the economic inequality is considered.

The table shows that in the late 2000s, the level of economic inequality by the Gini index in Russia was about 1.4 times higher than in Germany (the most prosperous of G20 country by this indicator) and was comparable with the level of inequality in the USA At the same time, GDP per capita (in PPP terms) in Russia was about 3 times lower than in Germany and 3.5 times lower than in the USA.

Below the G20 countries are compared by GDP per capita and the Gini index as for the end of the 2000s (Figure).

According to the comparison of countries by GDP per capita and the Gini index at the end of the 2000s the highest economic inequality by income in the group of G20 countries with upper-middle and low-middle income was observed in Brazil and South Africa (the BRICS) and Mexico and Argentina.

The relatively lower level of income inequality (below the median value of 0.37 ) was only in those economies of the G20 that are classified as high-income (excluding the U.S.), which was generally a characteristic of the early 1990 s, as well.

Analysis of data in Tables 3 and 4 reveals another particular feature associated with the dynamics of income inequality. Reduction in inequality over the period from the early 1990s till the end of the 2000s was seen only in four countries of the G20 (Turkey, Mexico, Brazil and the U.K.).

Table 4

Inequality by income indicators in G20

\begin{tabular}{|c|c|c|c|c|}
\hline \multirow{2}{*}{$\begin{array}{c}\text { G } 20 \\
\text { country-member }\end{array}$} & \multirow{2}{*}{$\begin{array}{l}\text { GDP per capita, the U.S. dollar, } \\
\text { current prices, PPP, } 2012\end{array}$} & \multirow{2}{*}{$\begin{array}{c}\text { Country groups by income } \\
\text { level }^{* *}\end{array}$} & \multicolumn{2}{|c|}{ Gini index } \\
\hline & & & size & year \\
\hline USA & 49922 & \multirow{10}{*}{ High-income } & 0.38 & 2010 \\
\hline Canada & 42734 & & 0.32 & 2010 \\
\hline Australia & 42640 & & 0.33 & 2010 \\
\hline Germany & 39028 & & 0.29 & 2010 \\
\hline UK & 36941 & & 0.34 & 2010 \\
\hline Japan & 36266 & & 0.34 & 2010 \\
\hline France & 35548 & & 0.30 & 2010 \\
\hline Korea & 32272 & & 0.31 & 2010 \\
\hline Saudi Arabia & 31275 & & $\mathrm{n} / \mathrm{a}$ & - \\
\hline Italy & 30136 & & 0.32 & 2010 \\
\hline Argentina & 18112 & \multirow{7}{*}{ Upper-middle-income } & 0.45 & 2010 \\
\hline Russia & 17709 & & 0.40 & 2009 \\
\hline Mexico & 15312 & & 0.47 & 2010 \\
\hline Turkey & 15001 & & 0.41 & 2010 \\
\hline Brazil & 11875 & & 0.55 & 2009 \\
\hline South Africa & 11375 & & 0.63 & 2009 \\
\hline China & 9162 & & 0.42 & 2009 \\
\hline Indonesia & 4977 & \multirow{2}{*}{ Low-middle-income } & 0.36 & 2010 \\
\hline India & 3829 & & 0.34 & 2010 \\
\hline
\end{tabular}

Composed by the authors based on: [20, 21, 22].

* Countries are ranked by GDP per capita decreasing as for the 2012.

${ }^{* *}$ Classification of the World Bank (Atlas method) is based on Gross National Income per capita in the U.S. dollar $\left(G N I_{t}^{\S}=\frac{G N I_{t}}{N_{t}} / e t^{*}\right.$, where $e t^{*}$ - conversion coefficient of national currency in US dollars in a year of $t$, GNI - Gross National Income in national currency in a year of $t, N_{t}$ - average annual population in a year of $\mathrm{t}$ ). Income classification is set each year. See: http://data.worldbank. org/about/country-classifications/country-and-lending-groups. 
A comparison of the levels of income inequality among the group of high-income countries and a group of upper- and lower-middle income of the G20 shows that the highest level of inequality in the first group equals to 0.38 (in the USA) corresponds to the minimum value of this index in the second group (marked for India and Indonesia). In the G20 group of upper- and lower-middle income countries, inequality at the late 2000s was more pronounced than in high-income countries: the median value of the index was 0.42 versus 0.32 , respectively.

Russia was a leader in growth rate of income inequality among the G20 countries with upper-middle-income over the period from early 1990s till late 2000s (second after China).

When comparing the level of economic inequality it is important to keep in mind the structure of the economy. A high proportion of raw materials (especially oil) in the structure of exports of the G20, along with Russia, is also typical for Canada, the UK, Saudi Arabia, Argentina, Mexico, Indonesia and India ${ }^{1}$. From this perspective, the inequality in Russia is consistently one of the highest (worse only in Argentina and Mexico).

Thus, international comparison shows: a) the explosive growth of inequality at the beginning of capitalist reforms (from 1990 till 1993); b) one of the highest growth rates of inequality among the G20 countries with upper-middle-income from the early 1990 till the late 2000s; and c) one of the highest levels of inequality among countries with similar export structures. These characteristics of Russian capitalism demonstrate economic inequality as the most acute problem for Russia.

\section{Cause and reason of social inequality in Russia: socio-economic aspect}

The main causes of social inequality are: 1) the inequality by income from employment, 2) low efficiency of personal income taxation, and 3) inadequate public spending on social protection. They are discussed below.

The calculations of inequality by income from employment are presented in Table 5.

The share of the lowest paid wage earners with income below the subsistence minimum budget of working age population rose from 3.1 to 14.1 per cent, i.e. more than in four times.

The share of medium-paid workers increased approximately by two times. But their share is very low (only about 5 per cent), while the number is about three times less than that of workers with the lowest wages.

\footnotetext{
${ }^{1}$ According to $[21,23]$.
}

Table 5

Groups of employees by real wages appropriate to different social standards of consumption (on average per month, \% of the total number of employees)

\begin{tabular}{|l|c|c|}
\hline \multirow{2}{*}{\multicolumn{1}{|c|}{ Groups }} & \multicolumn{2}{c|}{ Year } \\
\cline { 2 - 3 } & $\mathbf{1 9 8 6}$ & $\mathbf{2 0 1 1}$ \\
\hline Under 1 BSMw $^{*}$ & 3.1 & 14.1 \\
\hline From 1 BSMw to 3 BSMw & 59.1 & 49.3 \\
\hline From 3 BSMw to 7 BSMw & 35.5 & 29.2 \\
\hline From 7 BSMw to 11 BSMw & 2.1 & 4.9 \\
\hline More than 11 BSMw & 0.2 & 2.5 \\
\hline
\end{tabular}

Estimations are made by the expert of All-Russian Centre of Living Standard and are based on: [5, p. 31; 24, p. 111; 7, p. 128]. * BSMw - Budget of Subsistence Minimum of working age population.

The share of highly paid employees has increased by 12.5 times. However, their representation is very low at about 3 per cent of the employees, covering primarily engaged in mineral and fuel and energy sectors, as well as in the financial sector.

A consequence of the changes was twofold increase in inequality in the distribution of workers by wage. In 1990, the index of funds for this indicator was 7.8 while in $2010-14.4$ times. The Gini index (concentration index of wages) increased from 0.371 to 0.413 .

Inefficient taxation of personal income. Since 2001, Russia has moved to a flat tax rate on personal income. Meanwhile, the history of the global income tax and the practice of the majority of the countries are associated with the use of progressive taxation. The last aligns income on the basis that the income unit, taken from the rich, results in less loss of utility for him, than the increase in utility for the poor as a result of the transfer of that sum to him. Since the marginal utility of income is reduced at the same percentage as income increases regardless of income level, then at a particular shape of the income utility curve it is necessary to introduce the greater percentage of tax for those who earn more ${ }^{2}$.

When one of the world's lowest levels of personal income tax rate, regardless of their size, was introduced in 2001, there were arguments about the expected expansion of the tax based on pulling monetary income of the rich into the «light», and as a consequence, an increase of state income.

As it turned out, these arguments did not stand the test of practice. An absolute increase in the amount of tax occurred, but not as a result of flat rate introduction. It was due to the expansion of

\footnotetext{
2 These ideas were developed by D. Bernoulli, A. Pigou, F. Edgeworth et al [25, p. 35-38].
} 
the group of tax payers (the military, police and etc.) during that period. As for the impact of a flat rate on the legalization of «black» income, it still does not work. Those who did not pay at a rate of 60 in 1992, 35 in 1997-1998, 20-30 per cent in 1999-2000, do not pay in full at the rate of 13 per cent. Meanwhile, in other countries, citizens pay in full and at a higher (up to 70 percent) rates.

In addition, progressive taxation is aimed at: overcoming the glaring gap between wealth in the private and poverty in public sectors; increasing the accumulation of funds to finance vital public services (construction and maintenance of roads, schools, low-cost housing, etc.).

The answer to a question about the actual reasons for the introduction of the current system of personal income tax is that the Russian state mistakenly chose the interests of a relatively small social group that had a power to influence the politics, economy and finances of the country, instead the interests of the majority and the country as a whole.

Almost all developed countries have set a minimum tax-free income that is below average costs of reproduction of the labor force for the country (for the USA and Western Europe it is in the range of 5-6 thousand dollars a year). At this level of income, the employee may not only be free from income tax but also get a comprehensive range of social benefits [26, p. 67].

Thus, it is necessary to recognize the need to change the distribution mechanisms and to establish the tax burden depending on the size of income.

Inadequate public spending on social protection. Social protection is one of the sources of income increase in the low income group and of reduction of social inequality. Despite the legal framework, and numerous measures of social support, the level of social benefits remains low and does not allow to raise the income of the population in need up to the official poverty level. The lack of funds is extremely high in vulnerable families with children. This is mostly due to inad- equate government spending on social support in Russia, which lags far behind in this spending from the most developed countries in the group G20. For example, in 2010 the spending of social support were in the UK - 28, Germany - 31, Italy -30 , France -34 per cent of GDP. In Russia, they were more than two times lower at the level of 12.8 in 2010, and in $2011-11.9$ per cent of GDP $[27,28]$. Such under-funding of social protection, along with non-target nature of the fund spending are among the reasons for the high levels of social inequality in Russia.

\section{Conclusion}

Capitalist reforms from 1992 till 2012 were characterized by a decline in the living standard of the majority of the population; different dynamics of this decline for different social groups and a significant increase in economic inequality.

The explosive nature of the growth of economic inequality in the beginning of capitalist reforms (from 1990 till 1993); one of the highest growth rates among the G20 countries with upper-middle income (from early 1990s till late 2000s.); one of the highest levels of inequality among countries with a similar export structure - are the particular features of Russian capitalism. They reveal inequality as one of the most acute problems for modern Russia.

The Government has introduced «Forecast of Long-term Socio-economic Development of the Russian Federation for the Period till the Year 2030» [29], i.e. for the next 20 years. Here the problem of high social inequality is represented only indirectly. The planned increase in GDP may even lead to the aggravation of the problem of inequality, if the development of the economy is at the expense of the selected branches of the fuel and energy sector or of high-tech industries. In modern Russian conditions an attempt to meet the challenges of economic growth and at the same time to eradicate poverty will not reach a success until measures to reduce social inequality are developed and implemented.

\section{Reference}

1. Global Wealth Report. Credit Suisse Research Institute, October 2012.

2. Gontmaher E. (2013). Rossieskiye sotsialnyye neravenstva kak factor sotsialno-politicheskoy stabilnosti [Russian Social Inequalities as a Socio-Political Stability Factor]. Voprosy ekonomiki [Questions of Economics], 4.

3. Bobkov V. (2011). Sotsialnyye struktury I neravenstva raspredeleniya naseleniya po kachestvu i urovnyu zhizni [Social Structures and Inequality of Population Distribution by Quality and Level of Life]. Moscow, VTsUZh [All-Russian Centre of Living Standard], 24.

4. Bobkov V. M. et al. Kachestvo i uroven zhizni naseleniya v sovremennoy Rossii (1991-2005 gg.) [The Quality and Standard of Living of the Population in Modern Russia (1991-2005)]. Monography, 719.

5. ROSSTAT. 2011. Rossiyskiy statisticheskiy ezhegodnik [Russsian Statistical Yearbook], Moscow, Rosstat.

6. ROSSTAT. 1996. Uroven zhizni naseleniya Rossii [Standard of Living of the Population in Russia]. Mocsow, Rosstat. 
7. ROSSTAT. 2011. Sotsialnoye polozheniye i uroven zhzni naseleniya Rossii [Social Status and Standard of Living of the Population in Russia]. Moscow, Rosstat.

8. ROSSTAT. 2013. Rossiya v tsifrakh 2013: Kratkiy statisticheskiy sbornik [Russia in Figures: Short Russian Statistical book]. Moscow, Rosstat.

9. ROSSTAT. 2011. Dokhody, raskhody i potrebleniye domashnikh khozyaystv v 2010 godu [Revenues, Expenses and Household Consumption in 2010]. Moscow, Rosstat.

10. OECD. 2010. Human Development Report 2010 - 20th Anniversary Edition. The Real Wealth of Nations: Pathways to Human Development. UNDP. OECD statistic.

11. Narodnoye khozyaystvo SSSR v 1990 g. [The National Economy of the USSR in 1990]. Moscow, Finansy i statistika [Finance and statistics].

12. Putin V. (2013). Stroitelstvo spravedlivosti. Sotsialnaya politika dlya Rossii [Building Justice. Social Policy for Russia]. Komsomolskaya pravda, 13.02.2013.

13. Russia Longitudinal Monitoring survey, RLMS-HSE», conducted by Higher School of Economics and ZAO "Demoscope" together with Carolina Population Center, University of North Carolina at Chapel Hill and the Institute of Sociology RAS. (RLMSHSE sites: http://www.cpc.unc.edu/projects/rlms-hse, http://www.hse.ru/org/hse/rlms).

14. ROSSTAT. 2011. Platnoye obsluzhivaniye naseleniya v Rossii [Paid Services for the Population in Russia]. Moscow, Rosstat.

15. Abramova E. M., Aleksandrova O.A., Kulagina E.V, Loginov D.M. (2008). Obrazovatelnyye resursy domokhozyaystv [Educational Resources of Households]. Moscow, M-Studio.

16. Kislicina O. (2011). Zdorovye detey: tendentsii, factory riska i strategii sberezheniya [Children's health: Trends, Risk Factors and Strategies for Savings]. Moscow, Maks-Press.

17. Human Development Report, 2011. Published for the UNDP. Moscow, Ves Mir.

18. OECD. Divided We Stand: Why Inequality Keeps Rising, OECD Publishing, 2011. Available at: http://dx.doi. org/10.1787/9789264119536-en (date of access: 22.06.2013).

19. OECD Data Base. Available at: http://stats.oecd.org/Index.aspx?DataSetCode=IDD (date of access: 19.06.2013).

20. World Bank. World Development Indicators. 2013. Available at: http://data.worldbank.org/indicator (date of access: 19.06.2013).

21. IMF. World Economic Outlook Database. 2013. Available at: http://imf.org (date of access: 19.06.2013)

22. OECD. Income Distribution, OECD Social and Welfare Statistics. Available at: doi:10.1787/data-00654-en (date of access: 19.06.2013).

23. The Central Intelligence Agency (CIA). Available at: https://www.cia.gov/index.html (date of access: 23.06.2013).

24. ROSSTAT. 1997. Sotsialnoye polozheniye i uroven zhizni naseleniya Rossii [Social Status and Standard of Living of the Population in Russia]. Moscow, Rosstat.

25. Blaug M. (2005). 100 velikikh ekonomistv do Keynsa [100 Great Economists Before Keynes]. Ekonomicheskaya shkola [Economic school] St. Petersburg.

26. Bobkov V. et al. (2006). Sistema potrebitelskikh byudzhetov — osnova nalogooblazheniya semeynykh dokhodov [The System of Consumer Budgets - the Basis of Family Income Taxation]. Uroven zhizni naseleniya regionov Rossii [Living standard of region population of Russia], 7.

27. EUROSTAT. Available at: http://epp.eurostat.ec.europa.eu/portal/page/portal/eurostat/home (date of access: 17.06.2013).

28. ROSSTAT. Available at: www.gks.ru.

29. Ministry of Economic Development of the Russian Federation. 2013. Prognoz dolgosrochnogo sotsialno-ekonomicheskogo razvitiya Rossiyskoy Federatsii na period do 2030 goda [Forecast of Long-term Socio-economic Development of the Russian Federation for the Period till the Year 2030].

\section{Information about the authors}

Bobkov Vyacheslav Nikolaevich (Moscow, Russia) - Doctor of Economics, Professor, General Director, PJSC "All-Russian Centre of Living Standard” (29 4th Park street, Moscow, 105043, Russia, e-mail: bobkovvn@mail.ru)

Veredyuk Olesya Vasilevna (St. Petersburg, Russia) - PhD in Economics, Associate Professor, Faculty of Economics, St. Petersburg State University (62 Chaykovskogo street, St. Petersburg, 191123, Russia, e-mail: o.veredyuk@econ.pu.ru). 